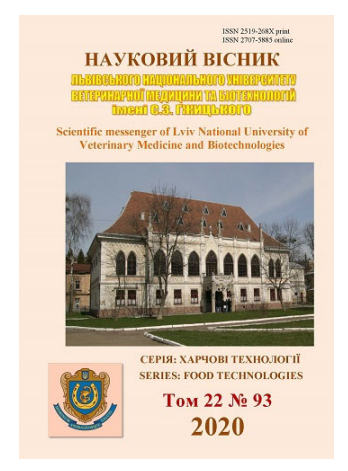

\author{
Науковий вісник Дьвівського національного університету \\ ветеринарної медицини та біотехнологій імені С.3. Гжицького. \\ Серія: Харчові технології \\ Scientific Messenger of Lviv National University \\ of Veterinary Medicine and Biotechnologies. \\ Series: Food Technologies
}

ISSN 2519-268X print ISSN $2707-5885$ online doi: 10.32718/nvlvet-f9310

https://nvlvet.com.ua/index.php/food

UDC 663.938-027.33:628.477.2:577.114.4

\title{
Obtaining and characterization of modified mannan from the coffee sludge
}

\author{
N. Cherno, K. Naumenko, L. Gural \\ Odesa National Academy of Food Technologies, Odessa, Ukraine
}

Article info

Received 05.02.2020

Received in revised form 09.03 .2020

Accepted 10.03.2020

Odesa National Academy of Food Technologies, Kanatna Str., 112 , Odessa, 65039, Ukraine. Tel.: +38-063-816-20-64 E-mail:shapkinak@gmail.com
Cherno, N., Naumenko, K., \& Gural, L. (2020). Obtaining and characterization of modified mannan from the coffee sludge. Scientific Messenger of Lviv National University of Veterinary Medicine and Biotechnologies. Series: Food Technologies, 22(93), 55-60. doi: 10.32718/nvlvetf9310

Mannans are polysaccharides of natural origin. Their main chain consists of residues of D-mannose. They have an immunomodulatory effect, able to induce macrophage activation, inhibit tumor growth and virus development, normalize blood cholesterol, etc. Manooligosaccharides are effective prebiotics The main way to obtain mannan is to extract their alkaline solutions. This makes it impossible to use this polysaccharide in food technologe. This study proposes a biotechnological method of producing watersoluble mannan from coffee sludge. As a source of mannan used a by-product of obtaining instant coffee at the Odessa Combine Food Concentrates which is formed in the processing of coffee beans Arabica. The chemical composition of this coffee sludge was investigated. It is dominated by water-insoluble carbohydrates which are represented by hemicellulose polysaccharides and cellulose. Analysis of the monosaccharide composition of hemicelluloses showed that the hydrolyzate contains mannose, glucose and galactose residues in a ratio of 6: 0,5: 3., which may indicate the presence of galactomannan in their composition. The developed method involves the treatment of the coffee sludge with enzyme preparation with beta-mannanase activity. The process was carried out in aqueous medium at temperature $50{ }^{\circ} \mathrm{C}$, varying the hydromodule in the range of $30 \ldots 50$, the ratio of enzyme: substrate $(1: 25,1: 50$ and 1:100) for $24 . . .72$ hours. This study presents the characteristics of the monomer composition and molecular weight distribution of polysaccharide samples obtained in this way. Only mannose was found in the hydrolyzate of water-soluble mannan. The rational conditions of enzymatic processing of raw materials are determined. The modified mannan is soluble in water. It contains the highest number of target fragments with a molecular weight of about $20 \mathrm{kDa}$ which are considered to be the most physiologically active. Subsequently the modified mannan can be used in nanotechnology functional food ingredients and dietary supplements.

Key words: mannan, a product of processing water-soluble coffee, water-soluble mannan.

\section{Отримання та характеристика модифікованого манану кавового шламу}

\author{
Н. К. Черно, К. І. Науменко, Л. С. Гураль
}

Одеська національна академія харчових технологї̈, м. Одеса, Україна

\begin{abstract}
Манани - ие полісахариди природного походження, основний ланиюг яких складається із залишків D-манози. Вони володіють імуномоделюючу дією, здатні індукувати активацію макрофагів, пригнічувати ріст пухлин та розвиток вірусів, сприяють загоєнню ран, нормалізації рівня холестерину в крові, а маноолігосахариди є ефективними пребіотиками. Основним способом вилучення манану є екстракція лужними розчинами. Це не дає можливості використовувати иього полісахариду в харчових продуктах. Запропоновано біотехнологічний спосіб отримання водорозчинного манану з кавового шламу. Як джерела манану використовували побічний продукт отримання розчинної кави на Одеському комбінаті харчових концентратів, що утворюється при переробиі кавових зерен сорту Арабіка. Досліджено хімічний склад даного кавового шламу. Встановлено, що у його складі переважає нерозчинна у воді вуглеводна складова, яка представлена полісахаридами геміщелюлоз, а також целюлозою. Аналіз моносахаридного складу геміщелюлоз показав, що у складі гідролізату містяться залишки манози, глюкози та галактози у процентних співвідношеннях 6:0, 5:3, що може свідчать про присутність у їхньому складі саме галактоманану. Розроблений спосіб передбачає обробку кавового шллму ферментним препаратом з бета-мананазною активністю. Процес проводили у водному середовищі при $T=50{ }^{\circ} \mathrm{C}$, варіюючи ГМ у діапазоні 30...50, співвідномення фермент:субстрат - 1:25, 1:50 та 1:100 протягом 24...72 годин. Надано харак-
\end{abstract}


теристику мономерного складу та молекулярно-масового розподілу вилучених зразків полісахариду. Обтрунтовано раціональні умови ензиматичної обробки сировини, внаслідок якої відбувається часткова деструкиія макромолекули нативного манану. Модифікований манан набуває здатності розчинятися у воді і містить найвишу кількість иільових фрагментів з молекулярною масою близько 20 кДа, фізіологічна активність яких вважається найбільш вагомою. Отриманий таким способом манан у перспективі може бути використаний у нанотехнологіях функиіональних харчових інгредієнтів та дієтичних добавок.

Ключові слова: манани, продукт переробки водорозчинної кави, водорозчинний манан.

\section{Вступ}

Наразі у світі проблема зміцнення здоров'я людини є однією із ключових. Здоров'я суспільства це показник, що відображає рівень соціальноекономічного розвитку країни. В Україні тенденція погіршення здоров'я населення набула високого рівня. Збіднення значної частини населення, погіршення екологічної ситуації, зростання темпів життя і розумових навантажень - все це призводить до зниження рівня здоров'я сучасної людини та викликає порушення системи імунітету, які лежать в основі патогенезу великого числа захворювань.

Одним зі шляхів підвищення імунного стану людини є корекція харчування, а саме: включення в раціони продуктів, які містять біологічно активні сполуки з імунокорегуючими ефектами.

Тому розробка нових біологічно активних інгредієнтів та дієтичних добавок, які володіють імунокорегуючими властивостями, є актуальною. До природних речовин, що володіють здатністю до корекції імунітету, належить низка некрохмальних полісахаридів, терапевтичний потенціал яких як регуляторів активації макрофагів вельми потужний.

Одним з перспективних біологічно активних полісахаридів $є$ манан. Цей полісахарид широко використовують у харовій промисловості для поліпшення структури харчових продуктів (Singh et al., 2018). Окрім того, манани мають багаточисленні фізіологічні ефекти, що позитивно впливають на стан здоров'я людини (Moreira \& Filho, 2008; Korolenko et al., 2019). Вони володіють вираженими імунофармакологічними властивостями, а манноолігосахаріди широко використовуються як пребіотики (Tizard et al., 1989).

Манани - це полісахариди, основний ланцюг яких складається із залишків D-манози. Вони трапляються у вищих (деревина хвойних порід, $10 \ldots 12 \%$ сухої маси) і нижчих рослинах, водоростях, мікроорганізмах (грибах, дріжджах та ін.). Даний клас полісахаридів поділяють на п'ять підкласів: лінійні манани, глюкоманани, галактоманани, галактоглюкоманани, манопротеїни (Moreira \& Filho, 2008; Sezer, 2014).

Біологічна активність мананів залежить від їх структурних особливостей, таких як моносахаридий склад, тип і конфігурації глікозидних зв'язків, молекулярна маса, розгалуженість та наявність певних функціональних груп (Ferreira et al., 2015; Singab et al., 2015; Liu et al., 2019).

Так, манан 3 дріжджів роду Candida albicans активніший, ніж маннан 3 дріжджів роду Saccharomyces cerevisiae. Ці відмінності можуть бути пов'язані 3 незначними структурними відмінностями у будові та розмірі їхніх макромолекул. Молекулярна маса манана $C$. albicans - від 5,5 до 20 кДа, а манана S. cerevisiae -понад 50 кДа (Sezer, 2014).
3 морської бактерії Edwardsiella tarda отримано два манани з різною довжиною ланцюга. Один являє собою біополімер 3 молекулярною масою близько 29 кДа, а інший - близько 70 кДа. Встановлено, що обидва полісахариди мають доволі значні антиоксидантні властивості. Однак манан з нижчою молекулярною масою асоціюють 3 вищою антиоксидантною активністю, ніж більш високомолекулярний (Guo et al., 2010). Варто зазаначити, що відповідь на питання, пов'язане $з$ взаємозв'язком фізіологічної активності мананів і величиною їхньої молекулярної маси, не є остаточно розв'язаним. Так, автор патенту Петерш Д. А. вважає, що високомолекулярні манани (тобто такі, що мають молекулярну масу понад 1000 кДа) мають вищу імуностимулювальну активність порівняно 3 мананами 3 меншими розмірами (Pietersz, 2017). Є припущення, що манани, які відрізняються за молекулярними масами, можуть сприяти вияву різних фізіологічних ефектів, саме цим пояснюються відмінності у поглядах дослідників на це питання.

На біологічну активність та технологічні властивості полісахаридів впливає наявність певних функціональних груп, зокрема ацетильних груп (Salah et al., 2017). Показано, що ацетилювання манану Aloe vera підвищує його в'язкість і термостабільність (Kumar \& Kumar, 2019). За структурою манану Aloe vera ацетильная група є єдиною неглікановою функціональною групою. Таким чином, ацетильна група може являти собою функціональний домен цього манану, який впливає щонайменше на деяку його топологічну структуру, біологічну активність і фізичні властивості. Дезацетилювання манану Aloe vera знижує його біологічну активність, зменшуючи його індуктивну активність щодо проліферації клітин. Таким чином, ацетильні групи відіграють важливу роль у структурі та фізико-біологічних властивостях мананів. Вони регулюють імунну систему, тимчасом як гідроксильні групи беруть участь у видаленні вільних радикалів (Chokboribal et al., 2015).

Моносахаридний склад мананів також відіграє роль у прояві біологічної активності. Відомо, що галактоглюкоманани 3 ялини Picea abies мають виражений пребіотичний ефект (Polari et al., 2002; Polari et al., 2012), галактоманани кавого шламу проявляють імуностимулювальну активність in vitro (Simões et al., 2010), а галактоманана 3 Punica granatum виявлють протипухлинну активність in vitro та in vivo (Joseph et al., 2013), глюкоманнани 3 Amorphophallus konjac благотворно впливають на рівень загального холестерину, ліпопротеїнів низької щільності, тригліцеридів, масу тіла (Sood et al., 2008). Манани з C. albicans проявляють певні імуномодулюючі властивості.

Лектини, які зв'язують манозу, присутні на макрофагах та можуть сполучатися з мананом і активува- 
ти імунну систему хазяїна за допомогою механізму розпізнавання чужорідності (Vasta et al., 1999). Рецептор манози розпізнає структуру повторюваних ланок, пов'язану з вуглеводами, які оточують інфекційні агенти, i опосередковує ендоцитоз i фагоцитоз (Aderem \& Underhill, 1999). Це розпізнавання приводить до передачі сигналу, продукції цитокінів та активації комплементу (Tzianabos, 2000). Активація макрофагів і стимуляція Т-клітин $є$ найпомітнішою біологічною активністю мананів - вони є потужними імунокоректорами зі значною активністю проти інфекційних захворювань і пухлин (Heinrichs et al., 2003).

Вище відзначено, що манани, як й інші представники некрохмальних полісахаридів, мають пребіотичні властивості. Так, дріжджові манани (манопротеїни) служать основним джерелом для виробництва дієтичних добавок на основі мананолігосахарідов, що широко використовуються як пребіотик в тваринництві та при виробництві продуктів харчування (Sohail et al., 2012).

Методи вилучення мананів залежать від природи сировинного джерела. 3 деяких рослинних об'єктів, в яких вони виконують резервну функцію, їх можна екстрагувати водою. 3 лігнофікованих джерел, де вони виконують структурну функцію, їх вилучають обробкою лужними розчинами. Однак отримані таким чином полісахариди $є$ нерозчинними у воді, тому частіше проводять їх ацетилювання, що своєю чергу модифікує нативну структуру полісахариду.

Одним з перспективних джерел отримання манану може бути кавовий шлам, який у промислових масштабах накопичується на підприємствах, що виробляють розчинну каву. Нині в Україні кавовий шлам застосовують для вироблення пелет, активованого вугілля, використовують як біопаливо, додають у будівельні матеріали. Проте як джерело фізіологічнофункціональних інгредієнтів його не використовують.

Мета дослідження. Дослідження присвячено розробленню способу модифікації лужнорозчинного манану кавового шламу з метою надання йому здатності розчинятися у воді.

Для досягнення поставленої мети були поставлені такі завдання:

- визначення та аналіз хімічного складу кавового шламу;

- підбір умов часткової ферментативної деструкції нативного манану з метою надання йому здатності розчинятися у воді;

- визначення та аналіз молекулярно-масового розподілу кожного фрагменту манану, що міститься у фермотолізатах, з метою обгрунтування раціональних умов ферментолізу.

\section{Матеріал і методи досліджень}

Об’єкт дослідження - побічний продукт виробництва розчинної кави на Одеському комбінаті харчових концентратів. У дослідах використовували кавовий шлам, що утворюється при переробці кавових зерен сорту Арабіка. Шлам відбирали безпосередньо після вилучення з нього водорозчинних речовин та висушували до вологості $7 \%$.
Масову частку білка визначали методом Кьєльдаля, масову частку ліпідів - методом Сокслета, а масову частку геміцелюлоз, целюлоз та лігніну за методами (Tzianabos, 2000).

Методом високоефективної рідинної хроматографії визначали моносахаридний склад гідролізатів.

Геміцелюлози вилучали зі знежиреного кавового шламу загальноприйнятим методом - екстракцією розчином $\mathrm{NaOH}$ (Gatenholm \& Tenkanen, 2004).

Для ферментативної деструкції використовували $\beta$-ендо-мананазу з активністю 50000 од., процес проводили у водному середовищі при $\mathrm{T}=50{ }^{\circ} \mathrm{C}$ протягом $24 \ldots 72$ годин, варіюючи ГМ у діапазоні $30 \ldots .50$, співвідношення фермент : субстрат - 1:25, 1:50 та 1:100. Після ферментативного гідролізу фермент піддавали інактивації, осад (денатурований фермент) відокремлювали центрифугуванням. Із надосадової рідини полісахарид осаджували етанолом.

Визначення молекулярно-масового розподілу зразків водорозчинного полісахариду, отриманих за різних умов обробки, здійснювали методом гельхроматографії на колонці 3 сефадексом G-50 ( $\mathrm{H}=38 \mathrm{~cm} ; \mathrm{D}=3,1 \mathrm{~cm} ; \mathrm{V}=121 \mathrm{~cm}^{3}$; Pharmacia, Швеція). Колонку калібрували маркерами 3 відомими молекулярними масами. В колонку вносили 10 мг досліджуваного продукту, елюент - вода; збирали фракції об'ємом 2 см³. Вміст вуглеводів у фракціях визначали антроновим методом.

\section{Результати та їх обговорення}

Хімічний склад кавового шламу подано в таблиці 1.

\section{Таблиця 1}

Хімічний склад кавового шламу, \% с. p.

\begin{tabular}{cc}
\hline Показник & Вміст \\
\hline Білок & 13,5 \\
Ліпіди & 10,6 \\
Вуглеводи, в тому числі: & 62,9 \\
геміцеллюлози & 36,9 \\
целюлоза & 26,0 \\
Лігнін & 8,8 \\
\hline
\end{tabular}

Встановлено, що у складі кавового шламу переважає нерозчинна у воді вуглеводна складова. Основна маса вуглеводів представлена полісахаридами геміцелюлоз, а також целюлозою. У гідролізаті геміцелюлоз ідентифіковані галактоза, глюкоза, маноза в процентному співвідношенні 4,4:0,5:5,5, знайдено також сліди ксилози та арабінози. Безумовно, на підставі отриманих даних визначити полісахаридний склад геміцелюлоз неможливо. Але присутність манану, виходячи 3 переважної кількості манози в гідролізаті, не викликає сумнів. Інша річ, що для встановлення категорії, до якої належить манан кавового шламу, потрібні додаткові дослідження. У літературних джерелах $є$ фрагментарні відомості щодо полісахаридів кавових зерен. Зокрема, Р. Редгвелл і М. Фішер вважають, що ïx складовою $є$ галактоманан (Redgwell \& Fischer, 2006). 
На основі результатів хроматографічного дослідження гідролізатів окремо виділених геміцелюлоз встановлено, що у складі сумарного препарату містяться залишки манози, глюкози та галактози у процентних співвідношеннях 6:0, 5:3. Отже, високою $\epsilon$ вірогідність присутності у складі геміцелюлоз саме галактоманану, хоча зважаючи на мінорну кількість залишків глюкози, не можна виключати, що манан кавового шламу може належати до категорії глюкогалактомананів.

Ставлячи за мету отримання низькомолекулярного водорозчинного полісахариду спробували обробити кавовий шлам $\beta$-ендо-мананазою, маючи на увазі здійсненні часткової ферментативної деструкції нативного манану без його вилучення 3 сировини. Вихід водорозчинних вуглеводів за різних умов обробки показано у таблиці 2.

Таблиця 2

Вихід водорозчинних вуглеводів, \% сухої маси шламу

\begin{tabular}{|c|c|c|c|c|}
\hline $\begin{array}{c}\text { № } \\
\text { зразка }\end{array}$ & $\begin{array}{l}\text { Співвідно- } \\
\text { шення E:S }\end{array}$ & ГМ & $\tau$ & $\begin{array}{c}\text { Вихід водороз- } \\
\text { чинних вугле- } \\
\text { водів, \% }\end{array}$ \\
\hline 1 & \multirow{9}{*}{$1: 25$} & \multirow{3}{*}{30} & 24 & 5,3 \\
\hline 2 & & & 48 & 10,9 \\
\hline 3 & & & 72 & 14,5 \\
\hline 4 & & \multirow{3}{*}{40} & 24 & 8,7 \\
\hline 5 & & & 48 & 18,7 \\
\hline 6 & & & 72 & 18,0 \\
\hline 7 & & \multirow{3}{*}{50} & 24 & 6,0 \\
\hline 8 & & & 48 & 17,6 \\
\hline 9 & & & 72 & 19,5 \\
\hline 10 & \multirow{9}{*}{$1: 50$} & \multirow{3}{*}{30} & 24 & 6,1 \\
\hline 11 & & & 48 & 10,1 \\
\hline 12 & & & 72 & 13,4 \\
\hline 13 & & \multirow{3}{*}{40} & 24 & 5,8 \\
\hline 14 & & & 48 & 10,4 \\
\hline 15 & & & 72 & 14,9 \\
\hline 16 & & \multirow{3}{*}{50} & 24 & 5,1 \\
\hline 17 & & & 48 & 9,8 \\
\hline 18 & & & 72 & 15,4 \\
\hline 19 & \multirow{9}{*}{$1: 100$} & \multirow{3}{*}{30} & 24 & 4,2 \\
\hline 20 & & & 48 & 5,8 \\
\hline 21 & & & 72 & 7,0 \\
\hline 22 & & \multirow{3}{*}{40} & 24 & 3,9 \\
\hline 23 & & & 48 & 4,3 \\
\hline 24 & & & 72 & 5,9 \\
\hline 25 & & \multirow{3}{*}{50} & 24 & 2,9 \\
\hline 26 & & & 48 & 3,7 \\
\hline 27 & & & 72 & 5,2 \\
\hline
\end{tabular}

Результати досліджень свідчать, що при збільшенні співвідношення E:S вихід водорозчинних вуглеводів значно зменшується, а при збільшенні ГМ - навпаки. Отже, найкращими умовами вилучення водорозчинного полісахариду 3 кавового шламу $\epsilon$ $\mathrm{E}: \mathrm{S}=1: 25 ; \Gamma \mathrm{M}=50 ; \tau=72$ год.

У складі гідролізату водорозчинного полісахариду знайдена виключно маноза. Отже, можна припустити, що у процесі ферментолізу відбувається відщеплення від молекули полісахариду залишків галактози i, мо- жливо, зменшення його молекулярної маси, що приводить до набуття ним здатності розчинятися у воді.

Оскільки відомо, що манан 3 нижчою молекулярною масою асоціюється 3 вищою фізіологічною активністю, наступний етап дослідження - визначити молекулярно-масовий розподіл кожного фрагмента манану, що міститься у фермотолізатах, з метою обгрунтування умов ферментолізу, за яких відбувається максимальне накопичення фрагментів 3 молекулярною масою в інтервалі значень 1 - 20 кДа (табл. 3).

\section{Таблиця 3}

Молекулярно-масовий розподіл досліджуваних зразків водорозчинного манану, \% співвідношення

\begin{tabular}{ccccc}
\hline \multirow{2}{*}{$\begin{array}{c}\text { № } \\
\text { зразка }\end{array}$} & \multicolumn{2}{l}{ Молекулярна маса, кДа } & \begin{tabular}{c} 
Вихід фракцій 3 \\
молекулярною ма- \\
\cline { 2 - 4 } сою до 20 кДа, \% від \\
сухої маси шламу
\end{tabular} \\
\hline 1 & 40,2 & 59,8 & 0 & 3,2 \\
2 & 49,5 & 41,1 & 9,4 & 4,5 \\
3 & 47,7 & 36,9 & 15,4 & 5,4 \\
4 & 30,5 & 60,5 & 0,9 & 5,3 \\
5 & 40,5 & 50,1 & 9,4 & 9,4 \\
6 & 48,7 & 30,5 & 21,3 & 5,8 \\
7 & 37,0 & 56,6 & 6,4 & 3,4 \\
8 & 41,9 & 42,4 & 15,7 & 7,5 \\
9 & 48,7 & 39,8 & 11,5 & 8,4 \\
10 & 31,7 & 44,7 & 23,6 & 2,7 \\
11 & 21,2 & 57,1 & 21,7 & 5,8 \\
12 & 37,0 & 33,8 & 29,2 & 4,5 \\
13 & 25,7 & 37,4 & 36,9 & 2,2 \\
14 & 31,5 & 42,5 & 26,0 & 4,4 \\
15 & 34,7 & 34,5 & 30,8 & 5,1 \\
16 & 53,4 & 39,7 & 6,9 & 2,0 \\
17 & 40,2 & 43,1 & 16,7 & 4,2 \\
18 & 24,2 & 39,1 & 36,7 & 6,0 \\
19 & 28,22 & 71,58 & 0,2 & 3,0 \\
20 & 17,58 & 81,23 & 1,19 & 4,7 \\
21 & 14,81 & 83,29 & 1,9 & 5,8 \\
22 & 36,15 & 63,85 & 0 & 2,5 \\
23 & 34,80 & 65,20 & 0 & 2,8 \\
24 & 25,30 & 65,46 & 9,24 & 3,9 \\
25 & 55,20 & 44,8 & 0 & 1,3 \\
26 & 40,5 & 59,5 & 0 & 2,2 \\
27 & 30,25 & 61,15 & 8,6 & 3,2 \\
\hline
\end{tabular}

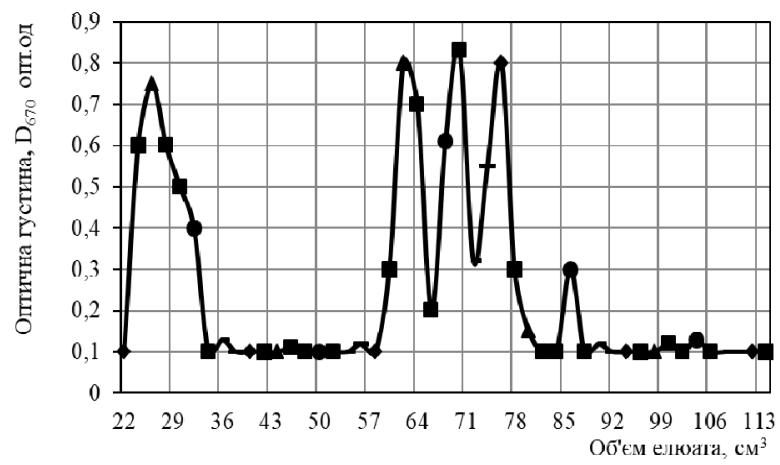

Рис. 1. Гель-хроматограма водорозчинного манану

Встановлено (табл. 3), що раціональними умовами для отримання водорозчинного манану з найбільшим вмістом складової, що містить фрагменти з молекулярною масою не більшою за 20 кДа, які здатні долати 
кишковий бар'єр і володіють кращою біодоступністю, $\epsilon$ співвідношення фермент : субстрат 1:25, тривалість гідролізу 48 годин, ГМ 40, гель-хроматографія якого (рис. 1) показала присутність в ньому 40,5 \% фракцій 3 молекулярною масою понад 20 кДа, 50,1 \% - 3 молекулярною масою близько 15 кДа і 9,4 \% - 3 молекулярною масою меншою ніж 0,5 кДа.

\section{Висновки}

Встановлено, що біополімерна складова кавового шламу представлена переважно полісахаридами, домінуючою компонентою яких є геміцелюлози, представлена переважно мананом. Розроблено біотехнологічний спосіб модифікації нативного манану, що дозволяє отримати водорозчинний полісахаридний продукт, в якому переважає частка фрагментів 3 підвищеною біодоступністю, здатних долати кишковий бар'єр. Умови ії отримання такі: співвідношення фермент : субстрат 1:25, тривалість гідролізу 48 годин, $\Gamma \mathrm{M}=40 \mathrm{~T}=50{ }^{\circ} \mathrm{C}$ у водному середовищі. Отриманий продукт у перспективі може бути використаний в нанотехнологіях функціональних харчових інгредієнтів та дієтичних добавок.

\section{References}

Aderem, A., \& Underhill, D. M. (1999). Mechanisms of phagocytosis in macrophages. Annu Rev Immunol., 17, 593-623. doi: 10.1146/annurev.immunol.17.1.593.

Chokboribal, J., Tachaboonyakiat, W., Sangvanich, P., Ruangpornvisuti, V., Jettanacheawchankit, S., \& Thunyakitpisal, P. (2015). Deacetylation affects the physical properties and bioactivity of acemannan, an extracted polysaccharide from Aloe vera. Carbohydr. Polym., 133, 556-566. doi: 10.1016/j.carbpol.2015.07.039.

Ferreira, S. S., Passos, C. P., Madureira, P., Vilanova, M., \& Coimbra, M. A. (2015). Structure-function relationships of immunostimulatory polysaccharides: A review. Carbohydr. Polym., 132, 378-396. doi: 10.1016/j.carbpol.2015.05.079.

Gatenholm, P., \& Tenkanen, M. (2004). Hemicelluloses: Science and Technology. American Chemical Society, 2004. 388. doi: 10.1021/bk-2004-0864.

Guo, S., Mao, W., Han, Y., Zhang, X., Yang, C., Chen, Y., Xu, J., Li, H., Qi, X., \& Xu, J. (2010). Structural characteristics and antioxidant activities of the extracellular polysaccharides produced by marine bacterium Edwardsiella tarda. Bioresour Technol., 101(12), 4729-4732. doi: 10.1016/j.biortech.2010.01.125.

Joseph, M. M., Aravind, S. R., George, S. K., Varghese, S., \& Sreelekha, T. T. (2013). A galactomannan polysaccharide from Punica granatum imparts in vitro and in vivo anticancer activity. Carbohydr Polym., 98(2), 1466-1475. doi: 10.1016/j.carbpol.2013.07.023.

Heinrichs, A. J., Jones, C. M., \& Heinrichs, B. S. (2003). Effects of mannan oligosaccharide or antibiotics in neonatal diets on health and growth of dairy calves. J. Dairy Sci., 86, 4064-4069. doi: 10.3168/jds.S00220302(03)74018-1.
Korolenko, A., Bgatova N. P., \& Vetvicka, V. (2019). Glucan and Mannan - Two Peas in a Pod. Int. J. Mol. Sci., 20(13), 3189. doi: 10.3390/ijms20133189.

Kumar, S., \& Kumar, R. (2019). Role of acemannan O-acetyl group in murine radioprotection. Carbohydr. Polym., 207, 460-470. doi: 10.1016/j.carbpol.2018.12.003.

Liu, C., Cui, Y., Pi, F., Cheng, Y., Guo, Y., \& Qian, H. (2019). Extraction, Purification, Structural Characteristics, Biological Activities and Pharmacological Applications of Acemannan, a Polysaccharide from Aloe vera: A Review. Molecules, 24(8), 1554. doi: 10.3390/molecules24081554.

Moreira, L. R., \& Filho, E. X. (2008). An overview of mannan structure and mannan-degrading enzyme systems. Appl. Microbiol. Biotechnol., 79, 165-178. doi: 10.1007/s00253-008-1423-4.

Pietersz, G. A. (2017). Ascend Biopharmaceuticals Pty Ltd. Use of high molecular weight mannan for inducing and/or enhancing an immune response US Patent 9597392. 201721 march

Polari, L., Ojansivu, P., Makela, S., Eckerman, C., Holmbom, B., \& Salminen, S. (2002). Isolation and characterization of galactoglucomannan from spruce (Picea abies). Carbohydr Polym, 48, 29-39.

Polari, L., Ojansivu, P., Makela, S., Eckerman, C., Holmbom, B., \& Salminen, S. (2012). Galactoglucomannan extracted from spruce (Picea abies) as a carbohydrate source for probiotic bacteria. J Agric Food Chem., 60(44), 11037-11043. doi: 10.1021/jf303741h.

Redgwell, R., \& Fischer, M. (2006). Coffee carbohydrates. Braz. J. Plant Physiol., 18(1), 165-174 doi: 10.1590/s1677-04202006000100012.

Salah, F., El Ghoul, Y., Mandhi, A., Majdoub, H., Jarroux, N., \& Sakli, F. (2017). Effect of the deacetylation degree onthe antibacterial and antibiofilm activity of acemannan from Aloe vera. Ind. Crops Prod., 103, 13-18. doi: 10.1016/j.indcrop.2017.03.033.

Sezer, A. D. (2014). Application of Nanotechnology in Drug Delivery. Marmara University, Turkey. doi: 10.5772/57028.

Singab, A. N., El-Hefnawy, H. M., Esmat, A., Gad, H. A., \& Nazeam, J. A. (2015). A Systemic Review on Aloe arborescens Pharmacological Profile: Biological Activities and Pilot Clinical Trials. Phytother. Res., 29(12), 1858-1867. doi: 10.1002/ptr.5483.

Singh, S., Singh, G., \& Arya, S. K. (2018). Mannans: An overview of properties and application in food products. Int. J. Biol. Macromol., 119, 79-95. doi: 10.1016/j.ijbiomac.2018.07.130.

Simões, J., Nunes, F. M., Domingues, M. R., \& Coimbra, M. A. (2010). Structural features of partially acetylated coffee galactomannans presenting immunostimulatory activity Carbohydr Polym, 79(2), 397-402. doi: 10.1016/j.carbpol.2009.08.020.

Sood, N., Baker, W. L., \& Coleman, C. I. (2008). Effect of glucomannan on plasma lipid and glucose concentrations, body weight, and blood pressure: systematic review and meta-analysis. Am J Clin Nutr., 88(4), 1167-1175. doi: 10.1093/ajcn/88.4.1167.

Sohail, M. U., Hume, M. E., Byrd, J. A., Nisbet, D. J., Ijaz, A., Sohail, A. et al. (2012). Effect of supplementation of prebiotic mannan-oligosaccharides and pro- 
biotic mixture on growth performance of broilers subjected to chronic heat stress. Poult Sci., 9(1), 22352240 doi: 10.3382/ps.2012-02182.

Tizard, I. R.,Carpenter, R. H., McAnalley, B. H., \& Kemp, M. C. (1989). The biological activities of mannans and related complex carbohydrates. Mol Biother., 1(6), 290-296.

Tzianabos, O. (2000). Polysaccharide Immunomodulators as Therapeutic Agents: Structural Aspects and Biologic Func- tion. Clinical Microbiol Reviews, 13(4), 523-533. doi: 10.1128/CMR.13.4.523.

Vasta, G., Quesenberry, R., Ahmed, M., \& O'Leary, H. (1999). C-type lectins and galectins mediate innate and adaptive immune functions: their roles in the complement activation pathway. Dev. Comp. Immunol., 23, 401-420. doi: 10.1016/s0145$305 \times(99) 00020-8$. 